\title{
Dealing with Cyanobacteria and Cyanotoxins: Engineering Viewpoints
}

\author{
Djamel Ghernaout ${ }^{1,2^{*}}$, Noureddine Elboughdiri ${ }^{1,3}$ \\ ${ }^{1}$ Chemical Engineering Department, College of Engineering, University of Ha'il, Ha'il, Saudi Arabia \\ ${ }^{2}$ Chemical Engineering Department, Faculty of Engineering, University of Blida, Blida, Algeria \\ ${ }^{3}$ Département de Génie Chimique de Procédés, Laboratoire Modélisation, Analyse, et Commande des systèmes, Ecole Nationale \\ d'Ingénieurs de Gabès (ENIG), Gabès, Tunisia \\ Email: ^djamel_andalus@hotmail.com
}

How to cite this paper: Ghernaout, D. and Elboughdiri, N. (2020) Dealing with Cyanobacteria and Cyanotoxins: Engineering Viewpoints. Open Access Library Journal, 7: e6363.

https://doi.org/10.4236/oalib.1106363

Received: April 26, 2020

Accepted: May 17, 2020

Published: May 20, 2020

Copyright $\odot 2020$ by author(s) and Open Access Library Inc.

This work is licensed under the Creative Commons Attribution International License (CC BY 4.0).

http://creativecommons.org/licenses/by/4.0/

(c) (i) Open Access

\begin{abstract}
Since the eutrophication of lakes stays a more and more spread event, cyanobacterial blooms are happening in numerous regions throughout the world. Even if numerous studies have been published, there is presently no outstanding technique for eliminating bloom. This review discusses the health hazards related to cyanotoxins, causes of tastes, and odors in water supplies. To deal with algae and cyanotoxins, the main engineers' tasks are briefly introduced. A special focus is accorded to the relationships between nutrients and cyanobacteria growth. Procedures for better nutrients input monitoring are presented. Main algae control technologies are briefly presented such as chemical control, aeration, mixing, and ultrasonic treatment. Several lab-scale implementations for algae removal are also examined. As ultrasonic treatment has attracted growing interest, its progress and dares are introduced. Avoiding chemicals addition, a judicious combination of aeration and mixing should attract more attention as the best available technology for dealing with algae and cyanotoxins directly on lakes. Green techniques like distillation and membrane processes should constitute the last stage of the treatment trains in the modern water treatment plant for securely retain cyanotoxins and organic matters. As precaution is better than treatment and with a view to reducing the external load, it is essential to control catchments via monitoring external nutrient sources, such as nitrogen and phosphorous, in water bodies.
\end{abstract}

\section{Subject Areas \\ Chemical Engineering \& Technology}

\section{Keywords}

Cyanobacteria, Cyanotoxins, Nitrogen (N), Phosphorous (P), 
Water Treatment, Best Available Technology (BAT)

\section{Introduction}

During the last years [1], numerous animal poisonings and deaths were reported, especially regarding seizure in dogs following drinking from, or just swimming in, polluted with cyanobacterial blooms [2] water sources. Unfortunately, the epidemiological proof has confirmed the event does not end only to animals since manifestations of intoxication were observed in humans following drinking water carrying cyanotoxins (cyanobacterial toxins) [1].

This review discusses the health hazards related to cyanotoxins, causes of tastes, and odors in water supplies. To deal with algae and cyanotoxins, the main engineers' tasks are briefly introduced. A special focus is accorded to the relationships between nutrients and cyanobacteria growth. Procedures for better nutrients input monitoring are presented. Main algae control technologies are briefly presented such as chemical control, aeration, mixing, and ultrasonic treatment. Several lab-scale implementations for algae removal are also examined. As ultrasonic treatment has attracted growing interest, its progress and dares are introduced.

\section{Health Hazards Related to Cyanotoxins}

The rapid expansion of manifestations and short-term grave health influences are the most common health hazards [3] linked to the occurrence of cyanotoxins. Groups related to higher hazard for developing intense symptoms comprise children who drink a greater volume of water in proportion to body weight than a grownup, or entities who are at risk of damage to organs such as dialysis patients, or individuals with liver disease [1].

It is established that subjection to microcystin (MC) (Figure 1) toxins is related to non-alcohol linked liver disease and could probably stimulate tumor development. Therefore, it is both a long-term subjection to low toxin concentrations as well as the short-term health impacts with high toxin concentrations that both worsen health. For water treatment plants' engineers, this implies it is important to realize if potable water carries blue-green algae and related MC toxins [1].

Health effects of cyanotoxins in humans may include headache, shortness of breath, abdominal pain, kidney damage, and liver inflammation [1].

\section{Causes of Tastes and Odors in Water Supplies}

Disagreeable taste and odor compounds are mostly produced by the occurrence of two metabolites generated by a set of cyanobacteria and actinomycete bacteria: 2-methylisoborneol (MIB) and geosmin (Figure 2). Such compounds are significant indicators of potable water quality and acceptability and could be subject to 


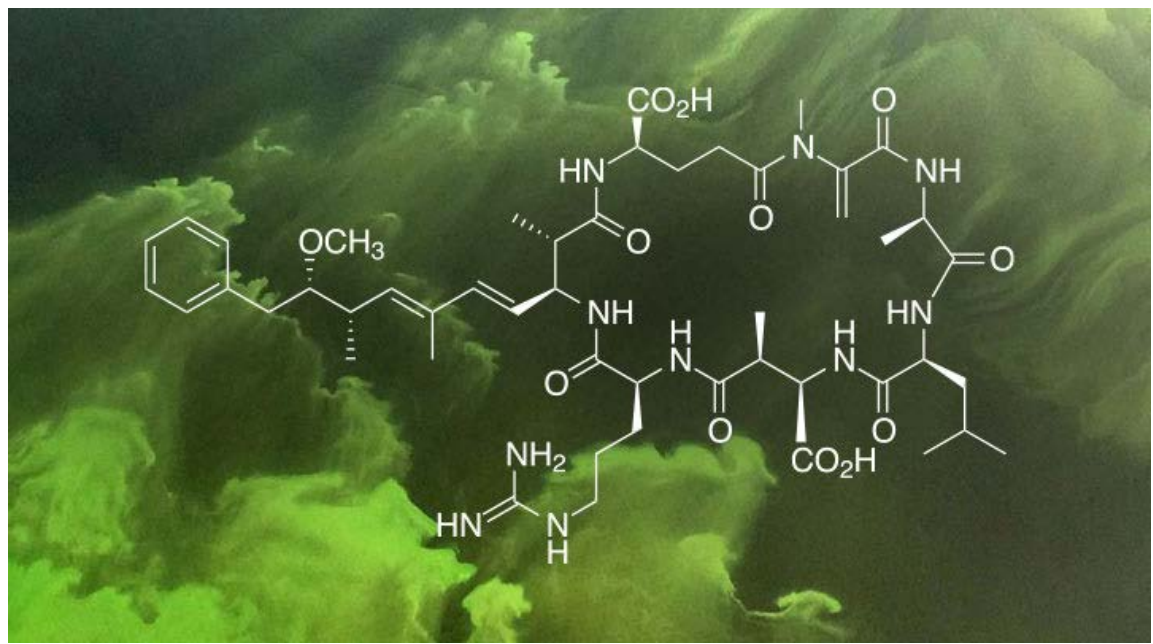

Figure 1. The structure of microcystin-LR (MC-LR) [1].

(a)

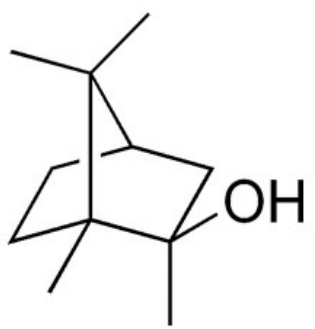

(b)

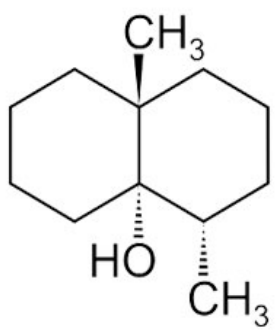

Figure 2. Structural formula for (a) 2-methylisoborneo (MIB) and (b) geosmin [1].

customers' complaints. These chemicals are noticeable at very small degrees (from 500 cells $/ \mathrm{mL}$ ); consequently, early water treatment is advised. Taste and odor chemicals are a more frequent trouble throughout warmer months when higher temperatures promote algal development. Even with unpleasant taste or odor of water, it could not be dangerous to drink. Reciprocally, the lack of compounds does not ensure that water is secure for consumption. To handle it, as an example, the Australian Drinking Water Guidelines [4] set apart two distinct types of guideline values: a health-related guideline value and an aesthetic guideline value [1].

Potable water quality guidelines propose tolerable levels for compounds that may be toxic to public health and thus are crucial for water supply authorities. Such guidelines are important in defining hazard management plans. Illustrations of guideline estimates for the level of total MCs in potable water that must be satisfied in individual countries are as follow [1]: Australia $1.3 \mu \mathrm{g} / \mathrm{L}$, South America $1.0 \mu \mathrm{g} / \mathrm{L}$, Canada $1.5 \mu \mathrm{g} / \mathrm{L}$.

\section{What Have Water Engineers to Observe?}

Primarily, for handling cyanobacteria in the potable water reservoir, it is valuable to recognize the species existing, dissolved toxins, cell counts, and taste and odors compounds. The latter cannot be immediately related to the poisoning of 
cyanobacterial blooms [2]; consequently, it may only be employed as a tool of global estimation and not as a standard of a warning system for a toxic cyanobacterial bloom. The estimation makes it easy to perceive the extent of the cyanobacteria trouble. Following the findings, management could carry out: the Alert Levels Framework, drinking water guidelines, control measures, or, water treatment [1].

Microscopic inspection and counting are frequently employed to discover the specie and evaluate cell plenty for colonial and filamentous cyanobacteria. The results are usually given as cell/mL and could be subsequently utilized in the Alert Levels Framework to assess the reservoir towards its cyanobacterial load. For making certain the protection of potable water supply, it is helpful to discover the specie of very likely poisonous cyanobacteria. Founded on such data, it becomes practical to adopt analytical techniques appropriate for setting toxin degrees. Additional procedures of detecting cyanotoxins are real-time monitoring programs collecting parameters like phycocyanin, which could let for a prompt warning of dangerous cyanobacterial bloom [1].

\section{Nutrients and the Development of Cyanobacteria}

In order to evaluate the danger of the development of cyanobacteria blooms following the interaction of ecological parameters, a set of procedures has been applied. A prime implicit hypothesis of the "susceptibility" ratings is that there is a link among phosphorus loading to a freshwater reservoir and algal productivity and biomass [1].

The most important nutrients touching the health of water bodies' ecosystems remain nitrogen $(\mathrm{N})$ and phosphorus $(\mathrm{P})$ [5]. Algae and aquatic plants depend on such nutrients for their expansion naturally [1].

Human activities generate an important surplus of nitrogen in the atmosphere either as nitrogen oxides or ammonia (Figure 3). It finishes deposited back onto land and washed into nearby water bodies. It is evaluated that atmospheric deposition over land has augmented threefold. Large atmospheric $\mathrm{N}$ deposition conducts to $\mathrm{N}$-saturation of watersheds and exporting nitrate further to streams, lakes, and estuaries [1].

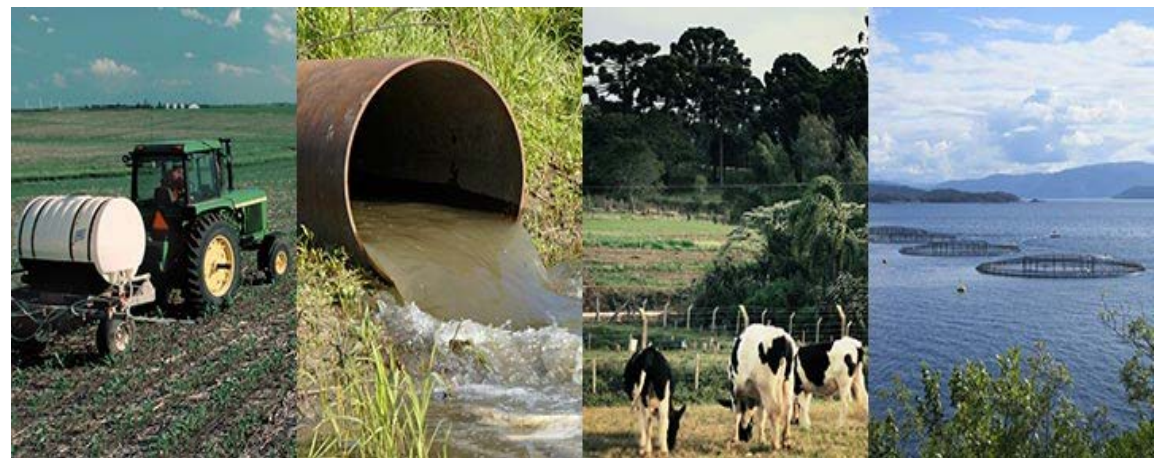

Figure 3. Nutrient pollution sources [1]. 


\section{Nutrient Inputs Monitoring}

The essential nutrient sources are frequently from the catchment or internally derived from sediment. With a view to reducing the external load, it is crucial to control catchments; however, it is costly, complicated, and frequently not sufficient by itself to avoid cyanobacterial blooms. Monitoring external nutrient sources predominantly does not reduce the nutrient loads and algal blooms in water bodies. Lakes appear to respond very slowly to nutrient control interventions. This is due to the fact that the nutrients stay in deposits for the long term. They replenish algal blooms and trigger further eutrophication [1] [6].

Real-time monitoring ${ }^{\mathrm{TM}}$ [7] of fundamental water quality variables and algae indicators assists in avoiding and anticipating the hazard of algae expansion. Following phytoplankton dynamics such as chlorophyll-a, phycocyanin, temperature, absorbance, $\mathrm{pH}$, and turbidity allow forecasting harmful algal blooms (HABs). The assessment is based on data about the concentration of algal biomass in a water body [7].

\section{Algae Control Techniques}

A more performant recuperation procedure is to dominate algal growth. Such a method aids in averting more gathering of nutrients in the deposits. The prime algae control techniques comprise chemical control, aeration, mixing, and ultrasound [6]. The ultrasonic algae control technique is rated the safest and environmentally-friendly solution for eutrophication from nutrient pollution. It is safe for fish and plants and could be employed for lakes and potable water reservoirs [1] (Figure 4).

\subsection{Chemical Control}

Such a technique implies treating the water with numerous chemicals like alum, lanthanum, or any other agents that precipitate or sequester the ionized orthophosphates. Aquatic herbicides employed to treat algae are called algaecides. They are frequently copper-based compounds (like copper sulfate, copper chelate communes, etc.) [6].

As a merit of chemical control, it is performant if it is applied on the entire surface [6].

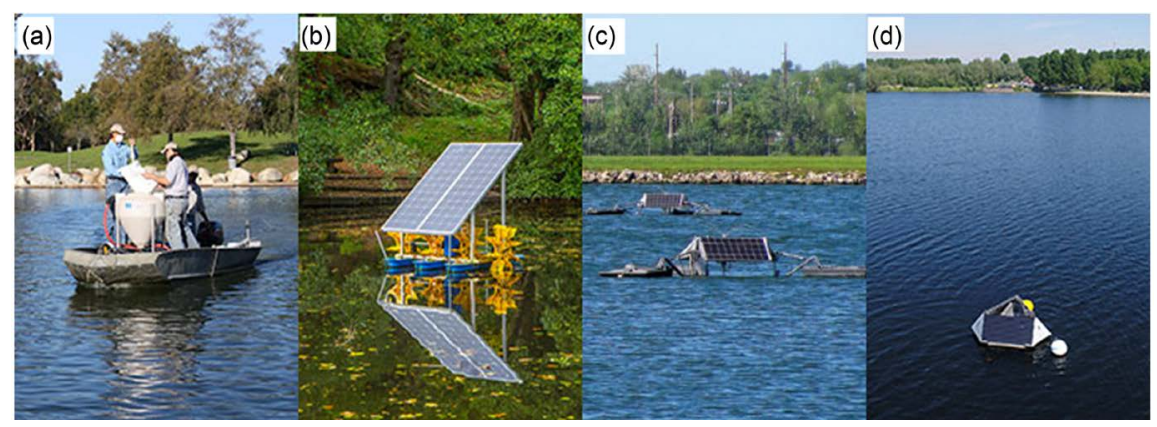

Figure 4. Algae control techniques (a) chemicals, (b) aeration, (c) mixing, and (d) ultrasonic algae control [6]. 
As for drawbacks, algaecides are costly and require periodic injection. They should be employed with attention because they could provoke the algal cell break. This causes the liberation of toxins into the water. Rapid decomposition of algal blooms could pollute water with elevated levels of algal toxins. This is poisonous for fish and plants. Algaecides could possess considerable long-term influences on the lake's ecological equilibrium. They remain not appropriate for huge water surfaces [6].

\subsection{Aeration Process}

Healthy degrees of dissolved oxygen in the pond remain vital [6]. Oxygen assists break down the decomposing vegetation and diverse nutrients in the water. Microorganisms facilitate break down the silt at the bottom. Aerobic and anaerobic bacteria both participate in degradation.

Aerobic degradation needs a constant supply of oxygen and increases when dissolved oxygen levels move toward the saturation levels. The first consequence of aerobic bacteria decay is carbon dioxide. Anaerobic decomposition is slower. The final products are organic chemicals such as alcohol and foul-smelling organic acids [6].

As the merits of aeration, it is an environmentally-friendly manner to freshen water bodies. It elevates the concentration of oxygen in the water. Aeration setups could assist in averting chemical introduction and form a healthy ecosystem. It could be applied for great ponds [6].

As for drawbacks, elevated prices for maintenance and labor, intense energy use. Aeration does not neutralize the algae directly; therefore, it is not always efficacious. It needs treatment of the full water surface [6].

\subsection{Mixing Process}

Mixing flows water to reach destratification in reservoirs. The method implicates mixing water to remove stratified layers. Epilimnion and Metalimnion are frequently moved around to dominate algae. The target is to evacuate the surface water from iron, manganese, and anoxic odors that frequently appear in the Hypolimnion layer. This causes circumstances less suitable for algae growth in certain layers [6].

As a benefit, artificial circulation generates less ecological harm than introducing chemical products. It remains mostly more efficacious in deep reservoirs (mean depth $>15 \mathrm{~m}$ ) [6].

As for drawbacks, flowing water requests elevated systems' maintenance because of wear and tear. These systems possess varying efficiencies on algae blooms. The impact on global cyanobacteria concentrations is polemic. In lakes, mixing frequently touches only surface layers near to destratifiers. In wide systems, mixing sediments could in fact augment the obtainable nutrients. This engenders more algae expansion in the short term. On the other hand, in the long-term, removals could be obtained [6]. 


\subsection{Ultrasonic Algae Control}

Ultrasounds are sound waves with frequencies above the limit of human hearing $(22 \mathrm{kHz})$ [6]. At particular frequencies, ultrasounds could aid control algae development [8]. Cyanobacteria employ gas vesicles for buoyancy and depth regulation. During the day, algae are photosynthesizing in the top layer (Figure 5). Carbon dioxide and nutrients dissolved in the water assist them to generate oxygen and polysaccharides. At night, the cyanobacteria cells empty their vacuole to sink to the bottom. There, they employ oxygen and nutrients to form biomass.

Ultrasound waves create a sound layer in the top layer of the water [9]. This touches algae buoyancy. The algae cells start sinking to the bottom. There, they cannot photosynthesize without sufficient light and finally die. Particular frequency programs should be utilized to guarantee efficacy. Selection is founded on the kind of algae that needs dominance. Algae could customize throughout seasons inside the same lake. The ultrasonic frequencies have to be orderly regulated for effective long-term algal dominance [6].

As merits, controlling algae with ultrasound is a well-established technology employed for numerous years [9]. It is an established performant for green and blue-green algae [8]. Ultrasound is environmentally-friendly and gentle to fish or plants. It could be applied to small and large lakes. Ultrasound in integrated with real-time monitoring helps to anticipate algal blooms and avert algal blooms [6].

As for drawbacks, ultrasound should comprise the total surface of the lake. Each spatial spot has to be treated for a minimum duration to reach total efficacy [6].

\section{Lab-Scale Applications for Algae Removal}

Wang et al. [10] proposed a novel two-step merged procedure to deal with this bloom removal. The first stage is the demobilization of the cyanobacteria [11] [12] [13] through injecting $\mathrm{H}_{2} \mathrm{O}_{2}$ [14] [15] [16]. They observed that $60 \mathrm{mg} / \mathrm{L}$ was the lowest efficient injection for a cyanobacterial level [17] [18] [19] corresponding to $100 \mathrm{mg} / \mathrm{L}$ chlorophyll-a. The second stage is the flocculation [20] [21] [22] and sedimentation of the demobilized cyanobacteria [23] [24] [25]. They noticed that the introduction of lake sediment clay ( $2 \mathrm{~g} / \mathrm{L})$ [26] plus polymeric ferric sulfate $(20 \mathrm{mg} / \mathrm{L})$ efficaciously deposited [27] them on the lake bottom (Figure 6).

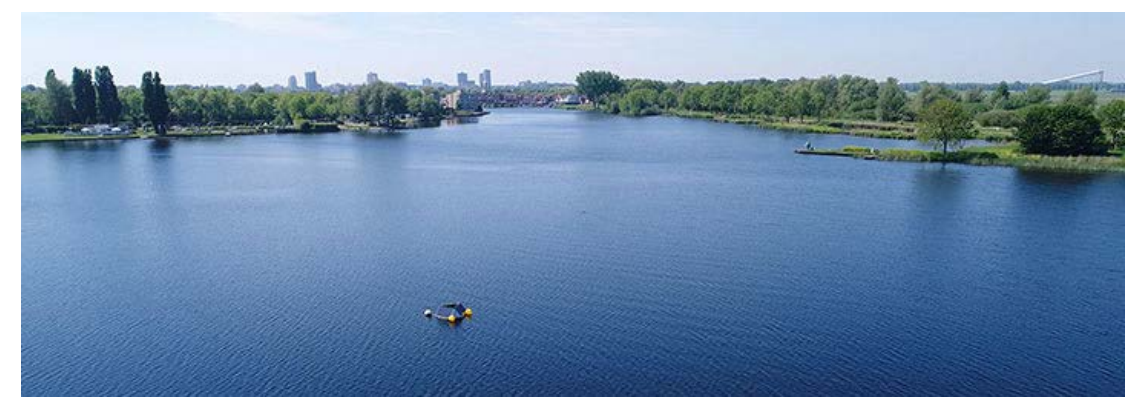

Figure 5. Clear lake treated by ultrasound for algae control [6]. 

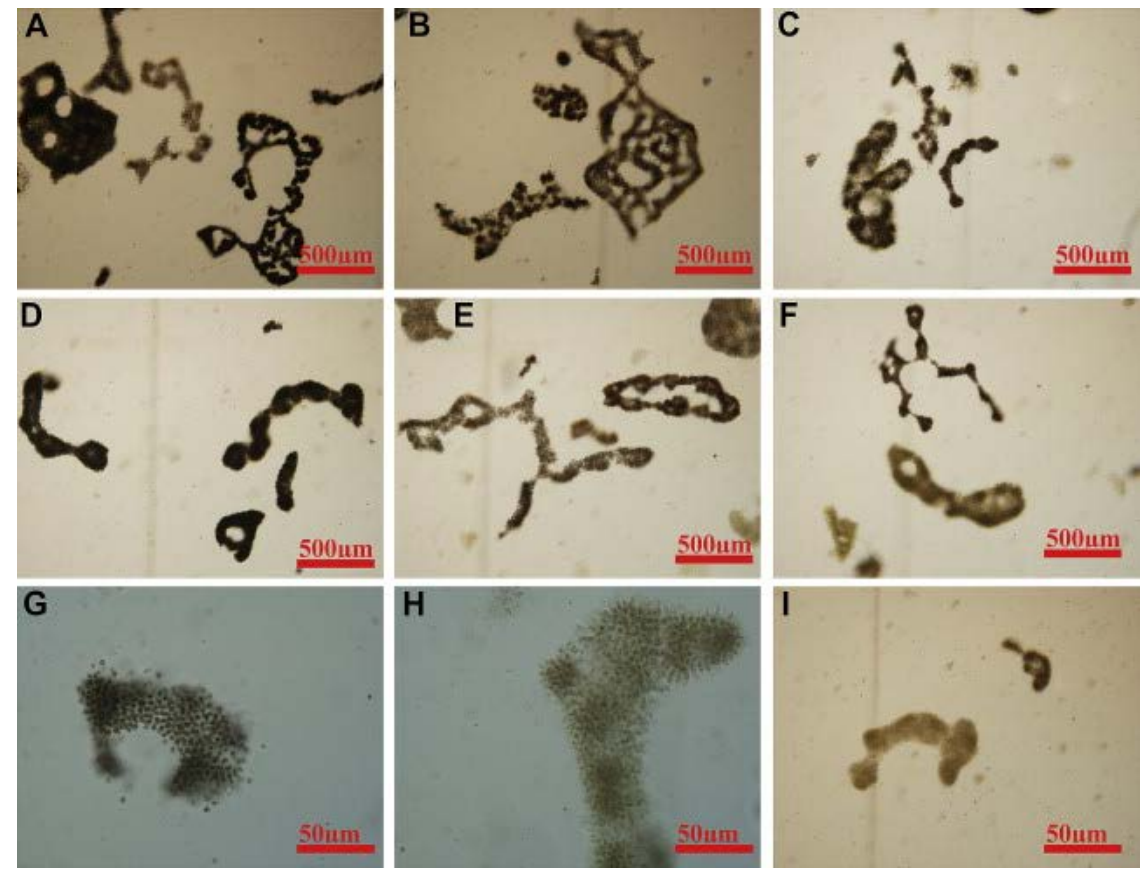

Figure 6. Morphological changes of Microcystis colonies in increasing $\mathrm{H}_{2} \mathrm{O}_{2}$. Here, (A), (B), (C), (D), (E) and (F) demonstrated different treating effect with 0, 10, 30, 60, 90 and $120 \mathrm{mg} / \mathrm{L} \mathrm{H}_{2} \mathrm{O}_{2}$ under light microscope, respectively. And (G), (H) and (I) showed colonial structure changes in 60,90 and $120 \mathrm{mg} / \mathrm{L} \mathrm{H}_{2} \mathrm{O}_{2}$, respectively [10].

Blooms of poisonous cyanobacteria like Microcystis aeruginosa sporadically take place inside wastewater treatment [28] [29] [30] lagoons during the warmer months, and can accordingly provoke pollution of downstream water and outages of the supply of recycled wastewater [31] [32] [33]. Rajasekhar et al. [34] performed lab-scale sonication $(20 \mathrm{kHz})$ on suspensions of $M$. aeruginosa isolated from a wastewater treatment [35] [36] [37] lagoon, and two other algal strains, Anabaena circinalis and Chlorella sp., to follow cell removal, development restraint, the liberation of $\mathrm{MC}$ and sonication yield in dominating the expansion of $M$. aeruginosa. For M. aeruginosa, for all sonication intensities and exposure times trialed, sonication conducted to an instantaneous decrease in the population, the biggest decrease rate happening during the first $5 \mathrm{~min}$. Sonication for 5 $\mathrm{min}$ at $0.32 \mathrm{~W} / \mathrm{mL}$, or for a longer exposure time (>10 $\mathrm{min})$ at a lower power intensity $(0.043 \mathrm{~W} / \mathrm{mL})$, conducted to an instantaneous augmentation in $\mathrm{MC}$ concentrations in the treated suspensions. Nevertheless, extended exposure (>10 min) to sonication at higher power intensities diminished the MC level considerably. Below the identical sonication circumstances, the order of reducing development restraint of the three algal species was: $A$. circinalis $>M$. aeruginosa $>$ Chlorella $s p$., establishing sonication possesses the capacity to selectively reduce/demobilize hazardous cyanobacteria from the algal communities [38] [39] [40] in wastewater treatment lagoons.

Zhang et al. [41] suggested a technique to demobilize M. aeruginosa through employing discharge plasma [42] taking at the gas-solution interface supplied by 
direct current (DC) [43] [44] [45] power. They utilized multiple analysis techniques comprising excitation-emission matrix (EEM) fluorescence and flow cytometry to divulge the demobilization pathway [46] [47] [48] of $M$. aeruginosa. They also followed photosynthetic pigment contents comprising phycocyanin, chlorophyll, and metabolites quantitatively. The DC glow discharge plasma provoked an augmented degree of reactive oxygen species (ROSs) [49] [50] [51], and the deterioration of $M$. aeruginosa cells is mostly ascribed to the oxidative stress involving ${ }^{\circ} \mathrm{OH}$ attack and $\mathrm{H}_{2} \mathrm{O}_{2}$ oxidation (Figure 7). Such results show that plasma oxidation may be viewed as an encouraging technique for demobilizing M. aeruginosa cells with concomitant reduction of MCs.
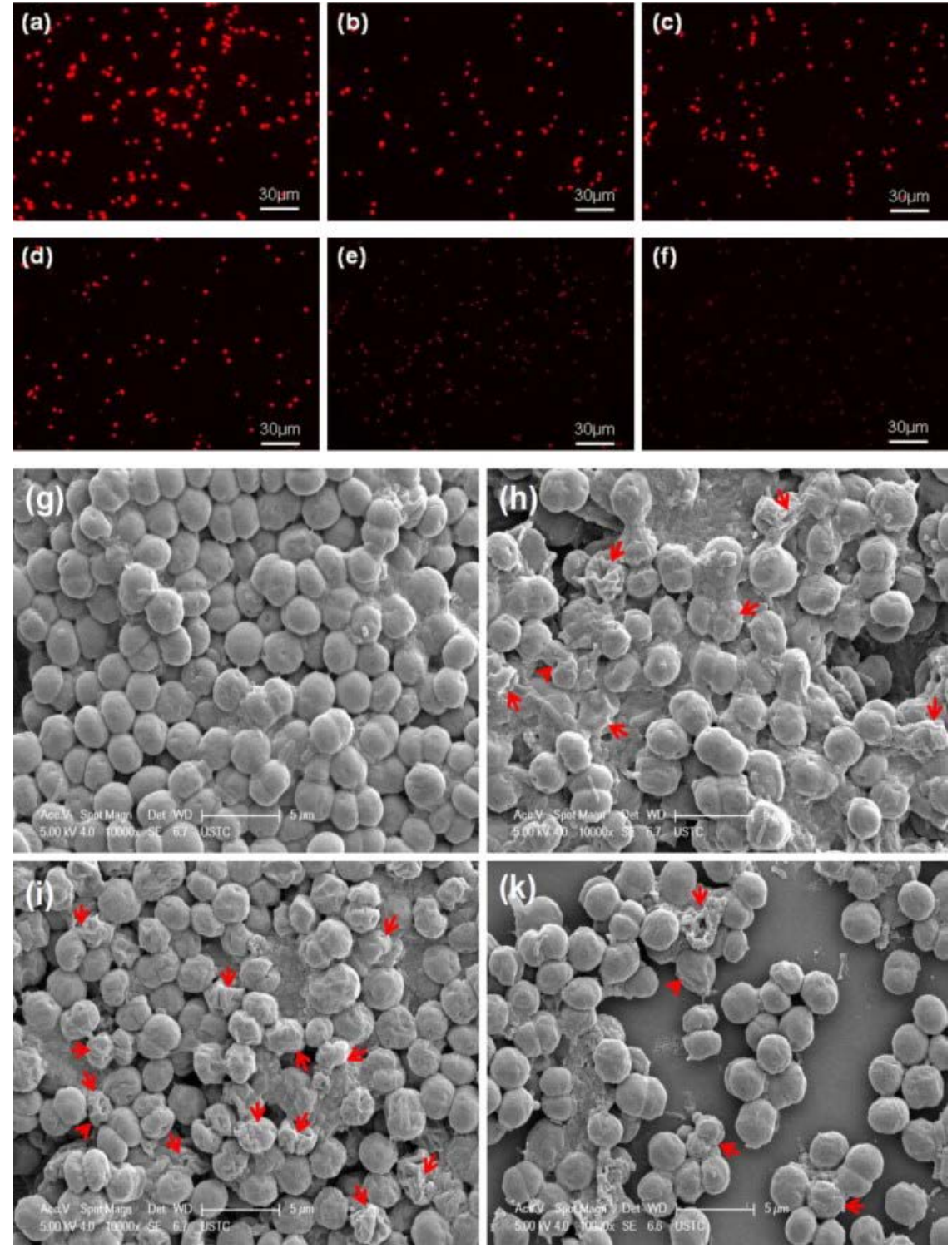

Figure 7. Morphological modifications of $M$. aeruginosa induced by discharge plasma oxidation. (a)-(f): Treated by discharge plasma for $0,2,4,8,10$, and 20 min observed by fluorescence microscopy; (g)-(k): Treated by discharge plasma for $0,4,8$, and $20 \mathrm{~min}$ observed by scanning electron microscopy [41]. 
To assess the demobilization and decomposition routes of $M$. aeruginosa under UV-C irradiation [36] and chlorination [52] [53] [54] [55], Ou et al. [56] employed poly-synchronous techniques. They examined extracellular dissolved organic matter (EDOM) [57] and intracellular dissolved organic matter (IDOM) characteristics [58] [59] [60] employing EEM fluorescence spectroscopy; however, they measured the levels of biochemical variables comprising protein, phycocyanin, chlorophyll-a, and MC-LR. They utilized transmission electron microscopy (TEM) to get ultrastructural images. EEM analysis divulged that protein-like matters were the main EDOM fluorescence component, whilst amino acid-like and protein-like matters composed IDOM with a little quantity of humic-like substances [61] [62] [63] [64]. Further, following the biochemical variables depicted that they had varying sensitivity below the demobilization responses. Poly-synchronous techniques asserted that UV-C irradiation was more suitable than chlorination for $M$. aeruginosa demobilization and decomposition. The first pathway of UV-C irradiation was direct photo-degradation and indirect oxidation via ROSs [65], which efficaciously decomposed the fluorescence EDOM and IDOM and provoked decay of cytoplasmic inclusions and intracellular bioorganic substances (Figure 8). Distinct from UV-C, the demobilization throughout chlorination was affected to the generation of $\mathrm{HOCl}$ that permeated into the cyanobacteria cells and provoked intracellular deterioration, followed with an incomplete decomposition of IDOM and toxic MC-LR (Figure 9).

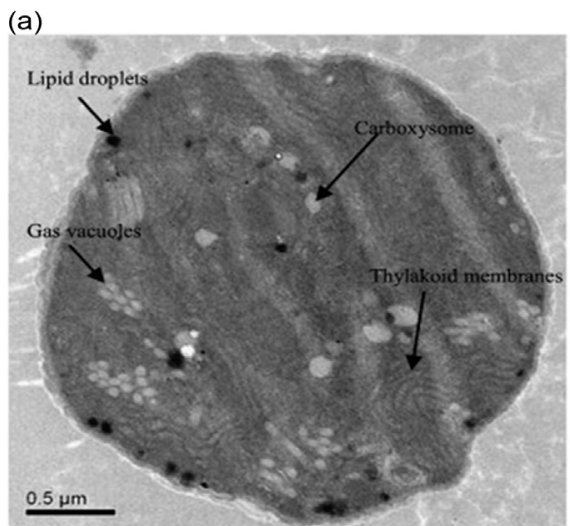

(c)

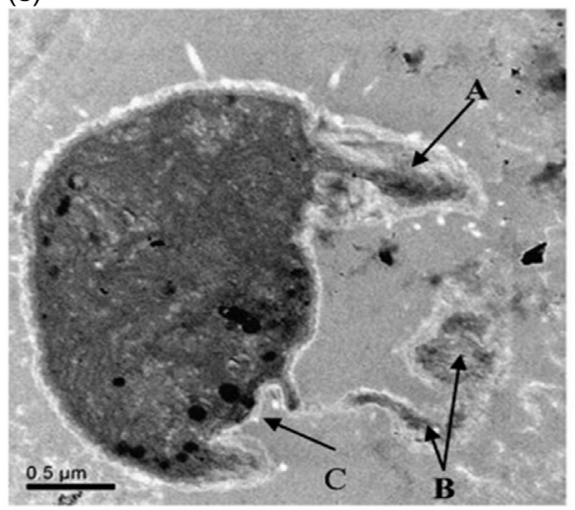

(b)

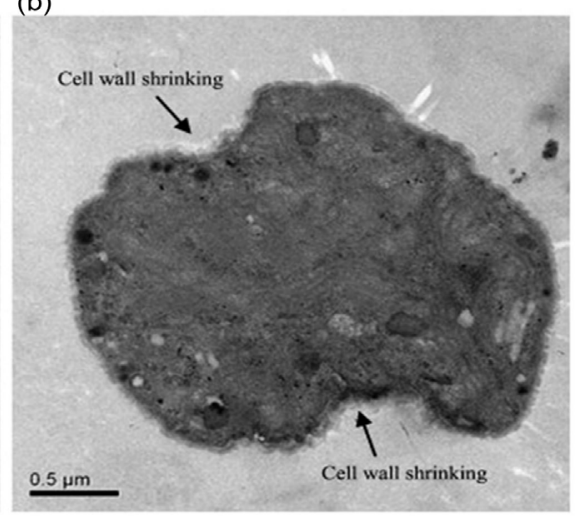

(d)

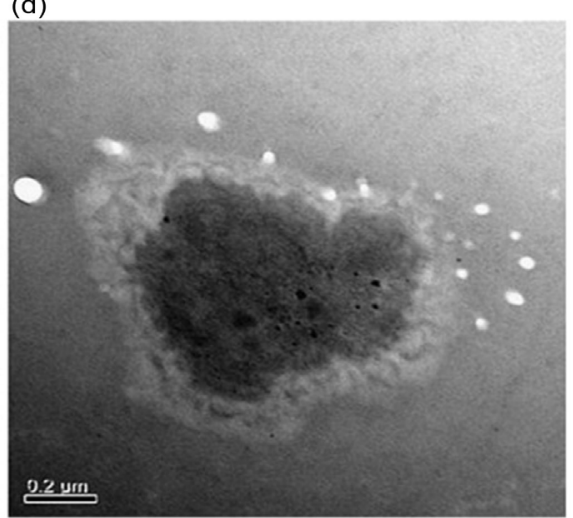

Figure 8. TEM ultrastructure images of normal (a) and UV-C treated (b), (c), and (d) $M$. aeruginosa cells [56]. 
(a)

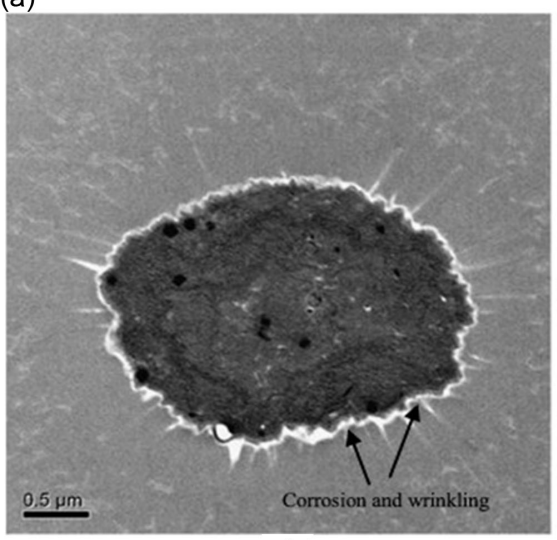

(b)

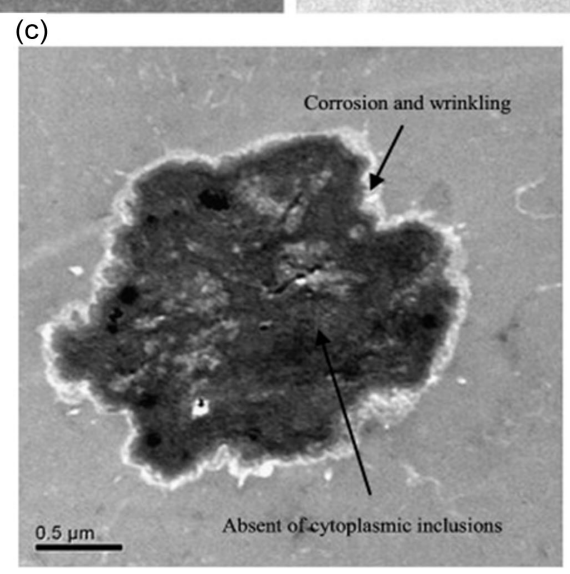

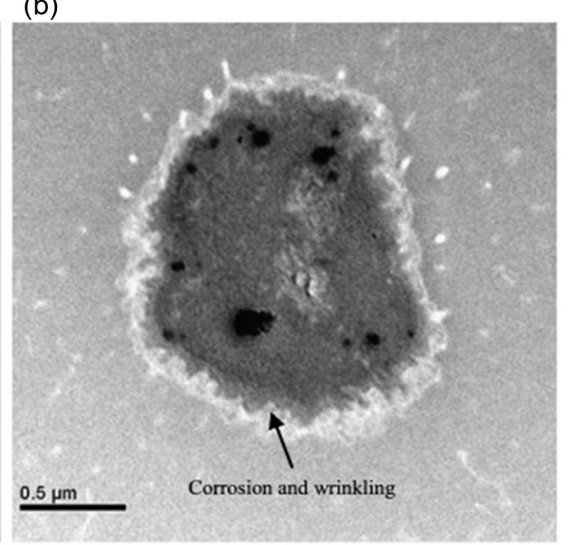

Figure 9. TEM ultrastructure images of chlorine treated $M$. aeruginosa cells [56].

\section{Ultrasonic Treatment: Progresses and Dares}

As seen above, sonication has attracted growing regard for algal control thanks to its low effect on ecosystems and nature [66] [67] [68]. The influences of ultrasound on algal cells become well established and working variables like frequency, intensity, and duration of exposure have been well examined. Nevertheless, most investigations have been restricted to laboratory data explanation because of intricate ecological conditions in the field. However, a couple of field and pilot trials in small reservoirs were published and the pertinence of ultrasound for HABs prevention and control remains below interrogation. There is a shortage of data on the upscaling of ultrasonication setups for HAB control on broader water bodies, taking into account field influencing parameters like rainfall, light intensity/duration, temperature, water flow, nutrients loading, and turbidity. Park et al. [69] focused on the dares and field circumstances of ultrasonic usages for dominating algal blooms. They performed a wide literature survey, from the fundamentals of ultrasound techniques to modern ultrasound laboratory and field surveys.

\section{Conclusions}

Throughout the globe, there is a trouble of cyanobacterial blooms and cyanotoxins in most of the surface freshwaters which are mostly utilized for potable 
water supply. Blocking and alleviating the repercussions of cyanobacterial blooms remain hard and repair actions are every so often out of the question to carry out; consequently, it is judicious to adopt firstly the protection operations [70]. From this work, the main conclusions emerge:

1) The first stage in protection is to dominate agricultural and urban runoff, to employ phosphate-free detergents, to regulate the drainage of the local septic systems, waste discharges, and to control spills of industrial waste [71] [72] [73]. A very small number of waterworks in the developing countries dominate cyanobacterial development, control cyanotoxins, and employ water treatments [74] [75] [76] for toxin elimination [70]. As the most frequent and most examined cyanotoxin, MCs constitute hard trouble for water authorities because they are recalcitrant to traditional water treatment [77] [78] due to their chemical stability in water. Thus, there is a request for substitutional water treatment techniques [79] [80] [81] to eliminate MCs.

2) Traditional water treatment techniques [82] [83] [84] stay restricted by elevated natural organic matter [85] [86] [87] and frequently conduct to the disintegration of cyanobacterial cells and coming liberation of cyanotoxins in water, with the hazard of forming poisonous by-products [88]. Intracellular cyanotoxins could be eliminated efficaciously via classical treatment [89] and assisted by convenient sorts of membranes [90] [91] [92]. Chloramination and UV treatment alone stay not performant in removing extracellular algal toxins. The toxins themselves cannot be eliminated through flocculation or by sand filtration. Activated carbon possesses the capability to absorb the toxins, even if the adsorption capacity stays restricted. Cyanotoxins are highly water-soluble and thus insufficiently adsorbed by activated carbon or reduced by additional filtration steps and flocculation [93] [94] [95]. Modern potable water treatment mostly implicates a hybridization of numerous technologies [96] [97] [98]. Advanced oxidation processes [99] [100] [101] have been proved to be performant in decomposing and detoxifying cyanotoxins [102] [103] [104], thus more efficacious than the classical ones [70] [105] [106]. As a new technique for removing cyanobacterial and algal cells, the sonochemical setup has been assessed during the previous two decades. Ultrasonication on cyanobacterial and algal cell growth works through deteriorating gas vacuoles and cell walls and decreasing photosynthetic activities. Ultrasonication impact on the development rate of algal cells and cyanobacteria is mainly a function of the sonication period, its frequency, and power. At high frequency $(1.7 \mathrm{MHz})$, high power free radicals are generated from the ultrasonication of water samples that harm cell structure and chlorophyll-a of cells. At low-frequency $(20 \mathrm{kHz})$, low power also leads to demolished cells. Hydroxyl radicals remain so crucial for decomposing toxins following sonication [107].

3) Considering carefully the cyanobacteria reproduction and their toxins release remains essential in dealing with the danger of cyanobacterial toxin troubles [108] [109]. In terms of the yields of cyanobacterial removal technologies, allowing in situ quantification of cyanobacterial existence with observing cyanobacteria in source waters stay crucial [70]. 


\section{Acknowledgements}

This research has been funded by the Research Deanship of University of Ha'il, Saudi Arabia, through the Project RG-191190.

\section{Conflicts of Interest}

The authors declare no conflicts of interest regarding the publication of this paper.

\section{References}

[1] LG Sonic (2020) Cyanotoxins Treatment Strategies for Water Utilities. https://www.lgsonic.com/blogs/cyanotoxins-treatment-strategies-for-water-utilities/

[2] LG Sonic (2020) Cyanobacterial Blooms: Causes, Dangers and Treatment. https://www.lgsonic.com/blogs/cyanobacterial-blooms/

[3] EPA (2019) Health Effects from Cyanotoxins. https://www.epa.gov/cyanohabs/health-effects-cyanotoxins

[4] National Health and Medical Research Council (NHMRC) (2018) Australian Drinking Water Guidelines. https://www.nhmrc.gov.au/about-us/publications/australian-drinking-water-guidelines

[5] LG Sonic (2019) Nutrient Pollution and Algal Blooms: Causes and Solutions. https:/www.lgsonic.com/blogs/nutrient-pollution-and-algal-blooms/

[6] LG Sonic (2019) How to Prevent Algal Blooms? Comparing Control Methods. https://www.lgsonic.com/blogs/how-to-prevent-algal-blooms/

[7] LG Sonic (2020) Water Quality Monitoring: Complete Sensor Package. https://www.lgsonic.com/water-quality-monitoring-software/

[8] LG Sonic (2017) How LG Sonic Ultrasound Technology Controls Algae.

[9] LG Sonic (2020) Ultrasonic Algae Control Technology. https://www.lgsonic.com/ultrasonic-algae-control-technology/

[10] Wang, Z., Li, D., Qin, H. and Li, Y. (2012) An Integrated Method for Removal of Harmful Cyanobacterial Blooms in Eutrophic Lakes. Environmental Pollution, 160, 34-41. https://doi.org/10.1016/j.envpol.2011.09.003

[11] Ghernaout, B., Ghernaout, D. and Saiba, A. (2010) Algae and Cyanotoxins Removal by Coagulation/Flocculation: A Review. Desalination and Water Treatment, 20, 133-143. https://doi.org/10.5004/dwt.2010.1202

[12] Ghernaout, D. and Ghernaout, B. (2012) On the Concept of the Future Drinking Water Treatment Plant: Algae Harvesting from the Algal Biomass for Biodiesel Production: A Review. Desalination and Water Treatment, 49, 1-18. https://doi.org/10.1080/19443994.2012.708191

[13] Ghernaout, D., Moulay, S., Ait Messaoudene, N., Aichouni, M., Naceur, M.W. and Boucherit, A. (2014) Coagulation and Chlorination of NOM and Algae in Water Treatment: A Review. International Journal of Environmental Monitoring and Analysis, 2, 23-34. https://doi.org/10.11648/j.ijema.s.2014020601.14

[14] Ghernaout, D. and Elboughdiri, N. (2020) Advanced Oxidation Processes for Wastewater Treatment: Facts and Future Trends. Open Access Library Journal, 7, e6139. https://doi.org/10.4236/oalib.1106139

[15] Ghernaout, D., Elboughdiri, N., Ghareba, S. and Salih, A. (2020) Electrochemical Advanced Oxidation Processes (EAOPs) for Disinfecting Water-Fresh Perspectives. Open Access Library Journal, 7, e6257. https://doi.org/10.4236/oalib.1106257 
[16] Ghernaout, D. (2013) Advanced Oxidation Phenomena in Electrocoagulation Process: A Myth or a Reality? Desalination and Water Treatment, 51, 7536-7554. https://doi.org/10.1080/19443994.2013.792520

[17] Ghernaout, D., Benblidia, C. and Khemici, F. (2015) Microalgae Removal from Ghrib Dam (Ain Defla, Algeria) Water by Electroflotation Using Stainless Steel Electrodes. Desalination and Water Treatment, 54, 3328-3337. https://doi.org/10.1080/19443994.2014.907749

[18] Ghernaout, D., Badis, A., Braikia, G., Matâam, N., Fekhar, M., Ghernaout, B. and Boucherit, A. (2017) Enhanced Coagulation for Algae Removal in a Typical Algeria Water Treatment Plant. Environmental Engineering and Management Journal, 16, 2303-2315. https://doi.org/10.30638/eemj.2017.238

[19] Al Arni, S., Amous, J. and Ghernaout, D. (2019) On the Perspective of Applying of a New Method for Wastewater Treatment Technology: Modification of the Third Traditional Stage with Two Units, One by Cultivating Microalgae and Another by Solar Vaporization. International Journal of Environmental Sciences \& Natural Resources, 16, Article ID: 555934. https://doi.org/10.19080/IJESNR.2019.16.555934

[20] Ghernaout, D., Elboughdiri, N., Ghareba, S. and Salih, A. (2020) Coagulation Process for Removing Algae and Algal Organic Matter-An Overview. Open Access Library Journal, 7, e6272. https://doi.org/10.4236/oalib.1106272

[21] Ghernaout, D. and Ghernaout, B. (2012) Sweep Flocculation as a Second Form of Charge Neutralisation: A Review. Desalination and Water Treatment, 44, 15-28. https://doi.org/10.1080/19443994.2012.691699

[22] Ghernaout, D., Ghernaout, B. and Kellil, A. (2009) Natural Organic Matter Removal and Enhanced Coagulation as a Link between Coagulation and Electrocoagulation. Desalination and Water Treatment, 2, 203-222. https://doi.org/10.5004/dwt.2009.116

[23] Kellali, Y. and Ghernaout, D. (2019) Physicochemical and Algal Study of Three Dams (Algeria) and Removal of Microalgae by Enhanced Coagulation. Applied Engineering, 3, 56-64.

[24] Ghernaout, D. (2019) Electrocoagulation Process for Microalgal Biotechnology: A Review. Applied Engineering, 3, 85-94.

[25] Ghernaout, D. and Elboughdiri, N. (2020) Eliminating Cyanobacteria and Controlling algal Organic Matter-Short Notes. Open Access Library Journal, 7, e6252.

[26] Ghernaout, D., Ghernaout, B. and Boucherit, A. (2008) Effect of pH on Electrocoagulation of Bentonite Suspensions in Batch Using Iron Electrodes. Journal of Dispersion Science and Technology, 29, 1272-1275. https://doi.org/10.1080/01932690701857483

[27] Ghernaout, D., Laribi, C., Alghamdi, A., Ghernaout, B., Ait Messaoudene, N. and Aichouni, M. (2018) Decolorization of BF Cibacete Blue (CB) and Red Solophenyle 3BL (RS) Using Aluminum Sulfate and Ferric Chloride. World Journal of Applied Chemistry, 3, 32-40. https://doi.org/10.11648/j.wjac.20180302.11

[28] Ghernaout, D., Alshammari, Y. and Alghamdi, A. (2018) Improving Energetically Operational Procedures in Wastewater Treatment Plants. International Journal of Advances in Applied Sciences, 5, 64-72. https://doi.org/10.21833/ijaas.2018.09.010

[29] Ghernaout, D. (2019) Reviviscence of Biological Wastewater Treatment: A Review. Applied Engineering, 3, 46-55.

[30] Ghernaout, D. and Elboughdiri, N. (2019) Upgrading Wastewater Treatment Plant to Obtain Drinking Water. Open Access Library Journal, 6, e5959.

https://doi.org/10.4236/oalib.1105959 
[31] Ghernaout, D. and Elboughdiri, N. (2020) Electrochemical Technology for Wastewater Treatment: Dares and Trends. Open Access Library Journal, 7, e6020.

[32] Ghernaout, D., Elboughdiri, N. and Ghareba, S. (2020) Fenton Technology for Wastewater Treatment: Dares and Trends. Open Access Library Journal, 7, e6045. https://doi.org/10.4236/oalib.1106045

[33] Ghernaout, D. and Elboughdiri, N. (2020) On the Treatment Trains for Municipal Wastewater Reuse for Irrigation. Open Access Library Journal, 7, e6088. https://doi.org/10.4236/oalib.1106088

[34] Rajasekhar, P., Fan, L., Nguyen, T. and Roddick, F.A. (2012) Impact of Sonication at $20 \mathrm{kHz}$ on Microcystis aeruginosa, Anabaena circinalis and Chlorella sp. Water Research, 46, 1473-1481. https://doi.org/10.1016/j.watres.2011.11.017

[35] Ghernaout, D. and Elboughdiri, N. (2020) Domestic Wastewater Treatment: Difficulties and Reasons, and Prospective Solutions-China as an Example. Open Access Library Journal, 7, e6141.

[36] Ghernaout, D. and Elboughdiri, N. (2020) UV-C/ $/ \mathrm{H}_{2} \mathrm{O}_{2}$ and Sunlight $/ \mathrm{H}_{2} \mathrm{O}_{2}$ in the Core of the Best Available Technologies for Dealing with Present Dares in Domestic Wastewater Reuse. Open Access Library Journal, 7, e6161. https://doi.org/10.4236/oalib.1106161

[37] Ghernaout, D. (2017) Water Reuse (WR): The Ultimate and Vital Solution for Water Supply Issues. International Journal of Sustainable Development Research, 3, 36-46. https://doi.org/10.11648/j.ijsdr.20170304.12

[38] Ghernaout, D. and Elboughdiri, N. (2020) Should We Forbid the Consumption of Antibiotics to Stop the Spread of Resistances in Nature? Open Access Library Journal, 7, e6138.

[39] Ghernaout, D. and Elboughdiri, N. (2020) Removing Antibiotic-Resistant Bacteria (ARB) Carrying Genes (ARGs): Challenges and Future Trends. Open Access Library Journal, 7, e6003. https://doi.org/10.4236/oalib.1106003

[40] Ghernaout, D. and Elboughdiri, N. (2020) Antibiotics Resistance in Water Mediums: Background, Facts, and Trends. Applied Engineering, 4, 1-6. https://doi.org/10.4236/oalib.1106003

[41] Zhang, H., Yang, L., Yu, Z. and Huang, Q. (2014) Inactivation of Microcystis aeruginosa by DC Glow Discharge Plasma: Impacts on Cell Integrity, Pigment Contents and Microcystins Degradation. Journal of Hazardous Materials, 268, 33-42. https://doi.org/10.1016/j.jhazmat.2014.01.001

[42] Ghernaout, D. and Elboughdiri, N. (2020) Disinfecting Water: Plasma Discharge for Removing Coronaviruses. Open Access Library Journal, 7, e6314. https://doi.org/10.4236/oalib.1106314

[43] Ghernaout, D. (2017) Microorganisms' Electrochemical Disinfection Phenomena. EC Microbiology, 9, 160-169.

[44] Ghernaout, D., Alghamdi, A. and Ghernaout, B. (2019) Microorganisms' Killing: Chemical Disinfection vs. Electrodisinfection. Applied Engineering, 3, 13-19.

[45] Ghernaout, D., Badis, A., Ghernaout, B. and Kellil, A. (2008) Application of Electrocoagulation in Escherichia coli Culture and Two Surface Waters. Desalination, 219, 118-125. https://doi.org/10.1016/j.desal.2007.05.010

[46] Ghernaout, D. and Ghernaout, B. (2010) From Chemical Disinfection to Electrodisinfection: The Obligatory Itinerary? Desalination and Water Treatment, 16, 156-175. https://doi.org/10.5004/dwt.2010.1085 
[47] Boucherit, A., Moulay, S., Ghernaout, D., Al-Ghonamy, A.I., Ghernaout, B., Naceur, M.W., Ait Messaoudene, N., Aichouni, M., Mahjoubi, A.A. and Elboughdiri, N.A. (2015) New Trends in Disinfection by-Products Formation upon Water Treatment. Journal of Research \& Developments in Chemistry, 2015, Article ID: 628833. https://doi.org/10.5171/2015.628833

[48] Ghernaout, D. (2018) Disinfection and DBPs Removal in Drinking Water Treatment: A Perspective for a Green Technology. International Journal of Advances in Applied Sciences, 5, 108-117. https://doi.org/10.21833/ijaas.2018.02.018

[49] Ghernaout, D. (2019) Virus Removal by Electrocoagulation and Electrooxidation: New Findings and Future Trends. Journal of Environmental Science and Allied Research, 2019, 85-90. https://doi.org/10.29199/2637-7063/ESAR-202024

[50] Ghernaout, D. (2019) Electrocoagulation and Electrooxidation for Disinfecting Water: New Breakthroughs and Implied Mechanisms. Applied Engineering, 3, 125-133.

[51] Ghernaout, D. and Elboughdiri, N. (2020) Controlling Disinfection by-Products Formation in Rainwater: Technologies and Trends. Open Access Library Journal, 7, e6162. https://doi.org/10.4236/oalib.1106162

[52] Ghernaout, D. (2017) Water Treatment Chlorination: An Updated Mechanistic Insight Review. Chemistry Research Journal, 2, 125-138.

[53] Ghernaout, D., Naceur, M.W. and Aouabed, A. (2011) On the Dependence of Chlorine by-Products Generated Species Formation of the Electrode Material and Applied Charge during Electrochemical Water Treatment. Desalination, 270, 9-22. https://doi.org/10.1016/j.desal.2011.01.010

[54] Ghernaout, D., Alghamdi, A., Aichouni, M. and Touahmia, M. (2018) The Lethal Water Tri-Therapy: Chlorine, Alum, and Polyelectrolyte. World Journal of Applied Chemistry, 3, 65-71. https://doi.org/10.11648/j.wjac.20180302.14

[55] Ghernaout, D. and Elboughdiri, N. (2020) Is Not It Time to Stop Using Chlorine for Treating Water? Open Access Library Journal, 7, e6007.

[56] Ou, H., Gao, N., Deng, Y., Qiao, J., Zhang, K., Li, T. and Dong, L. (2011) Mechanistic Studies of Microcystic aeruginosa Inactivation and Degradation by UV-C Irradiation and Chlorination with Poly-Synchronous Analyses. Desalination, 272, 107-119. https://doi.org/10.1016/j.desal.2011.01.014

[57] Ghernaout, D., Elboughdiri, N. and Ghernaout, B. (2020) Trends in Decreasing Disinfection by-Products Formation during Electrochemical Technologies. Open Access Library Journal, 7, e6142. https://doi.org/10.4236/oalib.1106337

[58] Ghernaout, D. (2014) The Hydrophilic/Hydrophobic Ratio vs. Dissolved Organics Removal by Coagulation: A Review. Journal of King Saud University-Science, 26, 169-180. https://doi.org/10.1016/j.jksus.2013.09.005

[59] Ghernaout, D. and Elboughdiri, N. (2020) Strategies for Reducing Disinfection by-Products Formation during Electrocoagulation. Open Access Library Journal, 7, e6076. https://doi.org/10.4236/oalib.1106076

[60] Ghernaout, D. and Elboughdiri, N. (2020) Disinfection by-Products: Presence and Elimination in Drinking Water. Open Access Library Journal, 7, e6140.

https://doi.org/10.4236/oalib.1106140

[61] Ghernaout, D., Ghernaout, B., Saiba, A., Boucherit, A. and Kellil, A. (2009) Removal of Humic Acids by Continuous Electromagnetic Treatment Followed by Electrocoagulation in Batch Using Aluminium Electrodes. Desalination, 239, 295-308. https://doi.org/10.1016/j.desal.2008.04.001

[62] Ghernaout, D., Ghernaout, B., Boucherit, A., Naceur, M.W., Khelifa, A. and Kellil, A. (2009) Study on Mechanism of Electrocoagulation with Iron Electrodes in Idea- 
lised Conditions and Electrocoagulation of Humic Acids Solution in Batch Using Aluminium Electrodes. Desalination and Water Treatment, 8, 91-99. https://doi.org/10.5004/dwt.2009.668

[63] Ghernaout, D., Mariche, A., Ghernaout, B. and Kellil, A. (2010) Electromagnetic Treatment-Bi-Electrocoagulation of Humic Acid in Continuous Mode Using Response Surface Method for Its Optimization and Application on Two Surface Waters. Desalination and Water Treatment, 22, 311-329. https://doi.org/10.5004/dwt.2010.1120

[64] Ghernaout, D., Irki, S. and Boucherit, A. (2014) Removal of $\mathrm{Cu}^{2+}$ and $\mathrm{Cd}^{2+}$, and Humic Acid and Phenol by Electrocoagulation Using Iron Electrodes. Desalination and Water Treatment, 52, 3256-3270. https://doi.org/10.1080/19443994.2013.852484

[65] Ghernaout, D. and Elboughdiri, N. (2020) An Insight in Electrocoagulation Process through Current Density Distribution (CDD). Open Access Library Journal, 7, e6142.

[66] Ghernaout, D. (2013) The Best Available Technology of Water/Wastewater Treatment and Seawater Desalination: Simulation of the Open Sky Seawater Distillation. Green and Sustainable Chemistry, 3, 68-88. https://doi.org/10.4236/gsc.2013.32012

[67] Ghernaout, D. (2018) Electrocoagulation Process: Achievements and Green Perspectives. Colloid and Surface Science, 3, 1-5. https://doi.org/10.11648/j.css.20180301.11

[68] Ghernaout, D. (2019) Greening Electrocoagulation Process for Disinfecting Water. Applied Engineering, 3, 27-31.

[69] Park, J., Church, J., Son, Y., Kim, K.-T. and Lee, W.H. (2017) Recent Advances in Ultrasonic Treatment: Challenges and Field Applications for Controlling Harmful Algal Blooms (HABs). Ultrasonics Sonochemistry, 38, 326-334. https://doi.org/10.1016/j.ultsonch.2017.03.003

[70] Pantelić, D., Svirčev, Z., Simeunović, J., Vidović, M. and Trajković, I. (2013) Cyanotoxins: Characteristics, Production and Degradation Routes in Drinking Water Treatment with Reference to the Situation in Serbia. Chemosphere, 91, 421-441. https://doi.org/10.1016/j.chemosphere.2013.01.003

[71] Ghernaout, D. (2017) Environmental Principles in the Holy Koran and the Sayings of the Prophet Muhammad. American Journal of Environmental Protection, 6, 75-79. https://doi.org/10.11648/j.ajep.20170603.13

[72] Ghernaout, D. (2018) Increasing Trends towards Drinking Water Reclamation from Treated Wastewater. World Journal of Applied Chemistry, 3, 1-9. https://doi.org/10.11648/j.wjac.20180301.11

[73] Ghernaout, D. (2018) Magnetic Field Generation in the Water Treatment Perspectives: An Overview. International Journal of Advances in Applied Sciences, 5, 193-203. https://doi.org/10.21833/ijaas.2018.01.025

[74] Ghernaout, D., Aichouni, M. and Alghamdi, A. (2018) Applying Big Data (BD) in Water Treatment Industry: A New Era of Advance. International Journal of Advances in Applied Sciences, 5, 89-97. https://doi.org/10.21833/ijaas.2018.03.013

[75] Alshammari, Y., Ghernaout, D., Aichouni, M. and Touahmia, M. (2018) Improving Operational Procedures in Riyadh's (Saudi Arabia) Water Treatment Plants Using Quality Tools. Applied Engineering, 2, 60-71.

[76] Ghernaout, D. (2019) Greening Cold Fusion as an Energy Source for Water Treatment Distillation: A Perspective. American Journal of Quantum Chemistry and Molecular Spectroscopy, 3, 1-5. 
[77] Ghernaout, D., Ghernaout, B. and Naceur, M.W. (2011) Embodying the Chemical Water Treatment in the Green Chemistry: A Review. Desalination, 271, 1-10. https://doi.org/10.1016/j.desal.2011.01.032

[78] Ghernaout, D. and Naceur, M.W. (2011) Ferrate(VI): In Situ Generation and Water Treatment: A Review. Desalination and Water Treatment, 30, 319-332. https://doi.org/10.5004/dwt.2011.2217

[79] Ghernaout, D., El-Wakil, A., Alghamdi, A., Elboughdiri, N. and Mahjoubi, A. (2018) Membrane Post-Synthesis Modifications and How It Came about. International Journal of Advances in Applied Sciences, 5, 60-64. https://doi.org/10.21833/ijaas.2018.02.010

[80] Ghernaout, D., Alshammari, Y., Alghamdi, A., Aichouni, M., Touahmia, M. and Ait Messaoudene, N. (2018) Water Reuse: Extenuating Membrane Fouling in Membrane Processes. International Journal of Environmental Analytical Chemistry, 2, 1-12. https://doi.org/10.11648/j.ajche.20180602.12

[81] Ghernaout, D. (2019) Brine Recycling: Towards Membrane Processes as the Best Available Technology. Applied Engineering, 3, 71-84.

[82] Ghernaout, D., Naceur, M.W. and Ghernaout, B. (2011) A Review of Electrocoagulation as a Promising Coagulation Process for Improved Organic and Inorganic Matters Removal by Electrophoresis and Electroflotation. Desalination and Water Treatment, 28, 287-320. https://doi.org/10.5004/dwt.2011.1493

[83] Ghernaout, D. (2017) Entropy in the Brownian Motion (BM) and Coagulation Background. Colloid and Surface Science, 2, 143-161.

[84] Ghernaout, D., Simoussa, A., Alghamdi, A., Ghernaout, B., Elboughdiri, N., Mahjoubi, A., Aichouni, M. and El-Wakil, A.E.A. (2018) Combining Lime Softening with Alum Coagulation for Hard Ghrib Dam Water Conventional Treatment. International Journal of Advances in Applied Sciences, 5, 61-70. https://doi.org/10.21833/ijaas.2018.05.008

[85] Ghernaout, D., Al-Ghonamy, A.I., Boucherit, A., Ghernaout, B., Naceur, M.W., Ait Messaoudene, N., Aichouni, M., Mahjoubi, A.A. and Elboughdiri, N.A. (2015) Brownian Motion and Coagulation Process. American Journal of Environmental Protection, 4, 1-15. https://doi.org/10.11648/j.ajeps.s.2015040501.11

[86] Ghernaout, D., Al-Ghonamy, A.I., Naceur, M.W., Boucherit, A., Messaoudene, N.A., Aichouni, M., Mahjoubi, A.A. and Elboughdiri, N.A. (2015) Controlling Coagulation Process: From Zeta Potential to Streaming Potential. American Journal of Environmental Protection, 4, 16-27. https://doi.org/10.11648/j.ajeps.s.2015040501.12

[87] Ghernaout, D. and Boucherit, A. (2015) Review of Coagulation's Rapid Mixing for NOM Removal. Journal of Research \& Developments in Chemistry, 2015, Article ID: 926518. https://doi.org/10.5171/2015.926518

[88] Ghernaout, D., Alghamdi, A., Touahmia, M., Aichouni, M. and Ait Messaoudene, N. (2018) Nanotechnology Phenomena in the Light of the Solar Energy. Journal of Environmental Chemical Engineering, 3, 1-8. https://doi.org/10.11648/j.jeece.20180301.11

[89] Djezzar, S., Ghernaout, D., Cherifi, H., Alghamdi, A., Ghernaout, B. and Aichouni, M. (2018) Conventional, Enhanced, and Alkaline Coagulation for Hard Ghrib Dam (Algeria) Water. World Journal of Applied Chemistry, 3, 41-55. https://doi.org/10.11648/j.wjac.20180302.12

[90] Ghernaout, D. and El-Wakil, A. (2017) Requiring Reverse Osmosis Membranes Modifications: An Overview. American Journal of Chemical Engineering, 5, 81-88. https://doi.org/10.11648/j.ajche.20170504.15 
[91] Ghernaout, D. (2017) Reverse Osmosis Process Membranes Modeling: A Historical Overview. Journal of Civil, Construction and Environmental Engineering, 2, 112-122.

[92] Ait Messaoudene, N., Naceur, M.W., Ghernaout, D., Alghamdi, A. and Aichouni, M. (2018) On the Validation Perspectives of the Proposed Novel Dimensionless Fouling Index. International Journal of Advances in Applied Sciences, 5, 116-122. https://doi.org/10.21833/ijaas.2018.07.014

[93] Irki, S., Ghernaout, D., Naceur, M.W., Alghamdi, A. and Aichouni, M. (2018) Decolorizing Methyl Orange by Fe-Electrocoagulation Process: A Mechanistic Insight. International Journal of Environmental Chemistry, 2, 18-28. https://doi.org/10.11648/j.ijec.20180201.14

[94] Ghernaout, D., Touahmia, M. and Aichouni, M. (2019) Disinfecting Water: Electrocoagulation as an Efficient Process. Applied Engineering, 3, 1-12.

[95] Ghernaout, D., Aichouni, M. and Touahmia, M. (2019) Mechanistic Insight into Disinfection by Electrocoagulation: A Review. Desalination and Water Treatment, 141, 68-81. https://doi.org/10.5004/dwt.2019.23457

[96] Ghernaout, D., Alghamdi, A. and Ghernaout, B. (2019) Electrocoagulation Process: A Mechanistic Review at the Dawn of Its Modeling. Journal of Environmental Science and Allied Research, 2, 51-67. https://doi.org/10.29199/2637-7063/ESAR-201019

[97] Ghernaout, D. (2019) Aeration Process for Removing Radon from Drinking Water: A Review. Applied Engineering, 3, 32-45. https://doi.org/10.11648/j.wjac.20180301.11

[98] Ghernaout, D. and Elboughdiri, N. (2019) Electrocoagulation Process Intensification for Disinfecting Water: A Review. Applied Engineering, 3, 140-147.

[99] Saiba, A., Kourdali, S., Ghernaout, B. and Ghernaout, D. (2010) In Desalination, from 1987 to 2009, the Birth of a New Seawater Pretreatment Process: Electrocoagulation: An Overview. Desalination and Water Treatment, 16, 201-217. https://doi.org/10.5004/dwt.2010.1094

[100] Belhout, D., Ghernaout, D., Djezzar-Douakh, S. and Kellil, A. (2010) Electrocoagulation of a Raw Water of Ghrib Dam (Algeria) in Batch Using Iron Electrodes. Desalination and Water Treatment, 16, 1-9. https://doi.org/10.5004/dwt.2010.1081

[101] Ghernaout, D. and Ghernaout, B. (2011) On the Controversial Effect of Sodium Sulphate as Supporting Electrolyte on Electrocoagulation Process: A Review. Desalination and Water Treatment, 27, 243-254. https://doi.org/10.5004/dwt.2011.1983

[102] Ghernaout, D. and Elboughdiri, N. (2019) Iron Electrocoagulation Process for Disinfecting Water: A Review. Applied Engineering, 3, 154-158.

[103] Ghernaout, D. (2019) Disinfection via Electrocoagulation Process: Implied Mechanisms and Future Tendencies. EC Microbiology, 15, 79-90.

[104] Ghernaout, D., Elboughdiri, N. and Al Arni, S. (2019) Water Reuse (WR): Dares, Restrictions, and Trends. Applied Engineering, 3, 159-170.

[105] Ghernaout, D., Elboughdiri, N. and Ghareba, S. (2019) Drinking Water Reuse: One-Step Closer to Overpassing the "Yuck Factor". Open Access Library Journal, 6, e5895. https://doi.org/10.4236/oalib.1105895

[106] Ghernaout, D. and Elboughdiri, N. (2019) Mechanistic Insight into Disinfection Using Ferrate(VI). Open Access Library Journal, 6, e5946.

https://doi.org/10.4236/oalib.1105946 
[107] Dehghani, M.H. (2016) Removal of Cyanobacterial and Algal Cells from Water by Ultrasonic Waves: A Review. Journal of Molecular Liquids, 222, 1109-1114. https://doi.org/10.1016/j.molliq.2016.08.010

[108] Ghernaout, D. and Elboughdiri, N. (2020) Environmental Engineering for Stopping Viruses Pandemics. Open Access Library Journal, 7, e6299.

[109] Ghernaout, D., Elboughdiri, N., Ghareba, S. and Salih, A. (2020) Disinfecting Water with the Carbon Fiber-Based Flow-through Electrode System (FES): Towards Axial Dispersion and Velocity Profile. Open Access Library Journal, 7, e6238.

https://doi.org/10.4236/oalib.1106238 